We thank Ms S Nip-Vlieg and Ms J Jacobs for their skilful technical help. This report is a part of the study on post-transfusion hepatitis, financed $b$ y the Prevention Fund of the Netherlands.

1 Van der Waart M, Snelting A, Cichy J, Wolters G, Schuurs A. Enzymeimmunoassay in the diagnosis of hepatitis, with emphasis on the detection of " $\mathrm{e}$ " antigen (HBeAG). $\mathcal{F}$ Med Virol 1978;3:43-9.

Schmitz H. Improved detection of virus-specific IgM antibodies. Elimination of non-specific IgM binding. $\mathcal{F}$ Gen Virol 1978;40:459-63.

3 Alter HJ. The dominant role of non-A, non-B in the pathogenesis of post-transfusion hepatitis: a clinical assessment. Clin in Gastroenterol $1980 ; 9: 155-70$.

4 Aach RD, Lander JJ, Sherman LA, et al. Transfusion-transmitted viruses: interim analysis of hepatitis among transfused and nontransfused patients. Vyas GN, Cohen SN, Scmid R, eds. Viral hepatitis. Philadelphia: Franklin Institute Press, 1978:383-96.

5 Alter JH, Purcell RH, Feinstone SM, Holland PV, Morrow AG. Non-A/ Non-B Hepatitis: $A$ Review and Interim Report of an Ongoing Prospective Study. Philadelphia: Franklin Institute Press, 1978:359-69.

(Accepted 4 November 1980)

Public Health Laboratory and Red Cross Blood Bank, Arnhem, Netherlands

J N KATCHAKI, MSC, MD, medical microbiologist

T H SIEM, MD, medical microbiologist

R BROUWER, MD, medical microbiologist ; director, Red Cross Blood Bank, Arnhem

Department of Medical Microbiology, University of Nijmegen, Nijmegen, Netherlands

A $M$ vaN LOON, PHD, virologist

J TH $M$ VAN DER LOGT, PHD, virologist

\section{Serum antibodies to anaerobic coccoid rods in patients with Crohn's disease or ulcerative colitis, and in medical and nursing staff}

The faecal flora of patients with Crohn's disease contain more anaerobic Gram-negative rods and Gram-positive coccoid rods of the genera Peptostreptococcus and Eubacterium than those of controls. ${ }^{12}$ The sera from patients with Crohn's disease also agglutinate certain strains of Peptostreptococcus and Eubacterium more frequently than sera from patients with other diseases and from healthy subjects. Based on this preliminary work four organisms, including two strains of Eubacterium contortum (Me 44 and Me 47), Eubacterium rectale (Me 46), and Peptostreptococcus productus (C18) have been used in agglutination studies to assess the possibility of patients having Crohn's disease. ${ }^{3}$ The composition of faecal flora in patients with Crohn's disease appeared to be independent of the duration and severity of the illness. In this study we reviewed the serology of patients with inflammatory bowel disease and of medical and nursing staff in close relationship to such patients. A healthy control group of blood donors was also included for comparison.

\section{Methods and results}

Sera were obtained from 20 patients with Crohn's disease and 17 with ulcerative colitis; further samples were taken from 19 nurses and 13 doctors who worked regularly in a clinic for inflammatory bowel disease, and from 12

Probability of subjects having Crohn's disease derived from agglutination reactions to two strains of Eubacterium contortum, Eubacterium rectale, and Peptostreptococcus productus

\begin{tabular}{lcccc}
\hline & $\begin{array}{c}\text { Definite } \\
(\mathrm{p}=0 \cdot 99-1 \cdot 0)\end{array}$ & $\begin{array}{c}\text { Probable } \\
(\mathrm{p}=0.95-0 \cdot 98)\end{array}$ & $\begin{array}{c}\text { Suspected } \\
(\mathrm{p}=0 \cdot 8-0 \cdot 94)\end{array}$ & $\begin{array}{c}\text { No Crohn's } \\
\text { disease } \\
(\mathrm{p}<0 \cdot 8)\end{array}$ \\
\hline $\begin{array}{l}\text { Patients with Crohn's } \\
\text { disease }(\mathrm{n}=20)\end{array}$ & 12 & 1 & 2 & 5 \\
$\begin{array}{l}\text { Patients with ulcerative } \\
\text { colitis }(\mathrm{n}=17)\end{array}$ & 4 & 1 & 1 & 11 \\
$\begin{array}{l}\text { Nurses }(\mathrm{n}=19) \\
\text { Doctors }(\mathrm{n}=13)\end{array}$ & 1 & & & 18 \\
Blood donors $(\mathrm{n}=12)$ & & & 13 \\
\hline
\end{tabular}

blood donors. All were tested in Rotterdam against the four strains of bacteria without knowledge of the source of samples. The probability of each subject having Crohn's disease was calculated by a technique described by van de Merwe. ${ }^{3}$ Sera were classified according to whether they indicated definite, probable, suspected, or no Crohn's disease (table). Results from agglutination tests were decoded in Cardiff.

Fifteen of the 20 patients with Crohn's disease were identified and in 12 the result of the serological test was considered definite (table). Six of the 17 patients with colitis also had a positive result $(p \geqslant 0.8)$, and four of these results were graded as definite. Of the 32 medical and nursing staff, only one had a positive result, and this subject had a history of undiagnosed abdominal pain. None of the 12 healthy blood donors had raised antibody titres.

\section{Comment}

The finding of abnormal faecal flora in patients with Crohn's disease is paralleled by the presence of corresponding serum antibodies in most of these patients. ${ }^{12}$ About one-tenth of patients with ulcerative colitis also have raised antibody titres. ${ }^{5} \mathrm{We}$ found none of these antibodies in medical and nursing staff who regularly cared for patients with inflammatory bowel disease. This supports the finding in a study of household contacts of a group of 10 patients with Crohn's disease. All household contacts had shared a home with a patient for five to 25 years and 25 out of 27 first-degree relatives and eight spouses had normal faecal flora. These findings suggest that Crohn's disease is unlikely to be contagious.

The agglutination test discriminates between healthy subjects and patients with either Crohn's disease or ulcerative colitis. In addition 15 of the 20 patients with Crohn's disease showed positive serological findings compared with only six of the 17 patients with colitis. Although this is an apparently high false-positive score, the difficulties in differential diagnosis with the two conditions may in some cases lead to reclassification in the future.

1 Wensinck F. The faecal flora of patients with Crohn's disease. Antonie van Leeuwenhoek $1975 ; 41: 214-5$.

2 Wensinck F. Faecal flora of Crohn's patients. Serological differentiation between Crohn's disease and ulcerative colitis. In: Weterman IT, Pena AS, Booth CC, eds. In: The management of Crohn's disease. Amsterdam: Excerpta Medica, 1976:103-7.

3 Van de Merwe, J. Serum antibodies to anaerobic coccoid rods in Crohn's disease. MD thesis. Erasmus University, Rotterdam, 1980.

4 Wensinck F, Schroder AM. The faecal flora of Crohn's patients and household contact family members. In: 2nd international workshop on Crohn's disease. In press.

${ }^{5}$ Matthews N, Mayberry JF, Rhodes J, et al. Agglutinins to bacteria in Crohn's disease. Gut 1980;21:5:376-80.

(Accepted 4 November 1980)

\section{University Hospital of Wales, Cardiff C14 4XW}

J MAYBERRY, BSC, MB, research registrar

J RHODES, MD, FRCP, consultant physician

N MATTHEWS, PHD, MRCPATH, senior lecturer, department of medical microbiology

Erasmus University, Rotterdam, Netherlands

F WENSINCK, MD, professor of medical microbiology

\section{An unusual presentation of opportunistic mucormycosis}

We describe a fatal case of mucormycosis which complicated the treatment of a patient with acute myeloblastic leukaemia. Obstruction of the superior vena cava was a misleading and unreported clinical manifestation of this infection.

\section{Case report}

A 64-year-old man was admitted with a two-week history of malaise. Examination showed pallor and severe oral candidiasis but no lymphadenopathy or hepatosplenomegaly. Investigation showed haemoglobin concentration of $9 \cdot 1 \mathrm{~g} / \mathrm{dl}$, platelets $75 \times 10^{9} / 1$, white cell count $5 \times 10^{\circ} / 1$ (neutrophils $3 \%$, lymphocytes $28 \%$, myeloblasts $69 \%$ ). Auer rods were demonstrated. Acute myeloblastic leukaemia was confirmed on marrow 